\title{
Pengaruh Penerapan Model Missouri Mathematics Project terhadap Kemampuan Komunikasi Matematika Siswa SMK Dwi Sejahtera Pekanbaru
}

\author{
Arifa Rahmi, Depriwana Rahmi \\ Program Studi Pendidikan Matematika, Fakultas Tarbiyah dan \\ Keguruan, UIN Sultan Syarif Kasim Riau \\ Email: depriwanar@gmail.com
}

\begin{abstract}
ABSTRAK. Penelitian ini bertujuan untuk menguji ada atau tidaknya pengaruh kemampuan komunikasi matematika siswa di SMK Dwi Sejahtera Pekanbaru yang belajar menggunakan model Missouri Mathematics Project. Penelitian ini adalah penelitian Quasi Eksperimen dan desain yang digunakan adalah Nonequivalent Control Group Design. Pengambilan data dalam penelitian ini menggunakan teknik observasi, dokumentasi dan tes.Hasil analisis data menggunakan uji t pada taraf signifikan $5 \%$ dimana nilai $t_{\text {hitung }}=2,42$ dan nilai $t_{\text {tabel }}=2,02$. Sehingga $t_{\text {hitung }}>t_{\text {tabel }}$ karena 2,42 $>2,02$, berarti $H_{o}$ ditolak dan $H_{a}$ diterima. Selain itu, adanya perbedaan dapat dilihat dari mean kelas eksperimen adalah 16,64 lebih tinggi dari pada mean kelas kontrol yaitu 13,68. Dengan adanya perbedaan tersebut, berartiterdapat pengaruh penerapan model Missouri Mathematics Projectterhadap kemampuan komunikasi matematika siswa SMK Dwi Sejahtera Pekanbaru.
\end{abstract}

Kata kunci : missouri mathematics project, pembelajaran konvensional, komunikasi matematika

\section{PENDAHULUAN}

Berdasarkan Peraturan Menteri Pendidikan Nasional RI No. 22 Tahun 2006, dijelaskan bahwa tujuan pembelajaran matematika adalah agar siswa 
memiliki kemampuan memahami konsep matematika, penalaran pada pola dan sifat, melakukan manipulasi matematika dalam membuat generalisasi, menyusun bukti atau menjelaskan gagasan dan pernyataan matematika,memecahkan masalah yang meliputi kemampuan memahami masalah, merancang model matematika, menyelesaikan model dan menafsirkan solusi yang diperoleh,mengomunikasikan gagasan dengan simbol, tabel, diagram atau media lain untuk memperjelas keadaan atau masalah.

Matematika menjadi sulit karena komunikasi bahasa matematika bersifat abstrak. Kondisi ini akan membuat siswa tidak bisa mendapatkan nilai yang baik. Sehingga kemampuan komunikasi tidak bisa mendukung belajar para siswa atas konsep-konsep matematika saat menggunakan objek matematika, memberikan laporan, penjelasan-penjelasan lisan, menggunakan diagram dan menggunakan simbol-simbol matematika.

Berdasarkan hasil wawancara dan observasi penulis dengan guru matematika SMK Dwi Sejahtera Pekanbaru yang dilakukan tanggal 11 Agustus 2014, penulis mendapatkan informasi bahwa sebagian besar siswa mengalami kesulitan dalam menyelesaikan soal yang berbentuk cerita dengan benar. Hal ini dapat dilihat dari nilai ulangan harian 34 orang siswa sebanyak 65\% siswa mendapat nilai di bawah Kriteria Ketuntasan Minimal (KKM).

Siswa tidak dapat menyelesaikan soal-soal tersebut dengan baik karena siswa kurang memahami maksud soal sehingga siswa kesulitan dalam mengubah permasalahan ke dalam kalimat matematika. Kira-kira $60 \%$ siswa kesulitan memahami ide-ide matematika dan menggambarkannya secara visual. Kira-kira 60\% siswa kesulitan menggunakan simbol, notasi dan istilah matematika sehingga siswa tidak bisa membuat model matematika yang dibutuhkan untuk menyelesaikan soal. Siswa masih belum mampu memahami, menginterpretasi dan mengevaluasi ide-ide matematika yang disajikan dalam bentuk tulisan, terlihat pada proses siswa menyelesaikan soal. Proses pembelajaran di kelas, hanya sekitar $10 \%$ siswa yang menunjukkan antusias dan keaktifannya saat proses pembelajaran. Masih terdapat siswa yang tidak memperhatikan dan belum terbiasa untuk mengemukakan ide. Akibatnya tujuan pembelajaran matematika terutama kemampuan komunikasi matematika belum tercapai dengan baik.

Berdasarkan permasalahan yang dikemukakan, hendaknya perlu dilakukan perbaikan dan pembaharuan dalam proses belajar mengajar matematika. Tujuan yang ingin dicapai dalam penelitian ini yaitu untuk mengetahui ada tidaknya pengaruh penerapan model Missouri Mathematics Project terhadap kemampuan komunikasi matematika siswa. 
Salah satu model pembelajaran yang menerapkan prinsip kerja sama adalah model Missouri Mathematics Project atau MMP. Model ini merupakan suatu model pembelajaran yang digunakan dalam pembelajaran matematika dengan menerapkan rencana kerja yang memiliki sasaran dalam mencapai tujuan pembelajaran matematika. Dirancang untuk menggabungkan kemandirian dan kerja sama antar kelompok. Kerja sama antar kelompok dapat berupa mengerjakan lembar kerja secara berkelompok yang akan membuat siswa saling membantu kesulitan masing-masing dan saling bertukar pikiran.

Krismanto dan Widyaiswara (2003) menyatakan bahwa model MMP terdiri atas lima tahap kegiatan yaitu review, pengembangan, latihan terkontrol, seatwork dan penugasan. Oleh karena itu, kemampuan komunikasi matematika siswa diharapkan dapat meningkatkan prestasi belajar siswa melalui pembelajaran menggunakan model MMP.

Menurut Artzt (Umar, 2012), melalui pembelajaran kooperatif yang dilakukan secara efektif dan melakukan penilaian yang cermat terhadap setiap komunikasi yang terjadi pada setiap aktivitas siswa baik individu maupun kelompok dalam mengembangkan kemampuan komunikasi matematika. Sehingga pembelajaran kooperatif dapat mengembangkan kemampuan komunikasi matematika karena pada pembelajaran ini terjadi aktifitas komunikasi siswa baik individu maupun dalam kelompok.

Model Missouri Mathematics Project merupakan bagian dari pembelajaran Cooperative Learning. Dengan demikian model Missouri Mathematics Projectdapat meningkatkan kemampuan komunikasi matematika siswa, baik itu dalam kegiatan diskusi ataupun dalam efektifitas penggunaan latihan.

Menurut Rosani,penggunaan latihan-latihan yang diberikandapat memperbaiki komunikasi matematika, penalaran, hubungan interpersonal, keterampilan membuat keputusan dan keterampilan menyelesaikan masalah.Sehingga siswa memiliki kemampuan untuk mengeksplorasi, menyusun konjektur dan memberikan alasan logis, kemampuan untuk menyelesaikan masalah, mengomunikasikan ide dan menggunakan matematika sebagai alat komunikasi, serta menghubungkan ide-ide tersebut.

Dalam penelitian ini penulis mengacu pada penelitian terdahulu yang relevan terhadap penelitian yang dilaksanakan saat ini. Penelitian yang dilakukan oleh Jannah, dkk (2013) menunjukkan bahwa terdapat peningkatan pemahaman dan sikap positif siswa SMK 1 Karanganyar kelas XI dengan model pembelajaran Missouri Mathematics Project pada materi fungsi. 


\section{METODE PENELITIAN}

Penelitian ini dilaksanakan pada semester ganjil tahun ajaran 2014/2015 yaitu mulai tanggal 10 November sampai 29 November 2014 di SMK Dwi Sejahtera Pekanbaru. Populasi pada penelitian ini adalah seluruh siswa SMK Dwi Sejahtera Pekanbaru tahun ajaran 2014/2015. Jumlah sampel pada penelitian ini adalah 25 orang siswa kelas XI TKJ sebagai kelas eksperimen yang menerapkan model Missouri Mathematics Project dan 23 orang siswa kelas XI R4sebagai kelas kontrol menerapkan pembelajaran konvensional.

Penelitian ini adalah penelitian quasi eksperimen karena penulis ingin mengetahui pengaruh suatu perlakuan terhadap suatu variabel. Menurut Sugiyono (2012), penelitian ini mempunyai kelompok kontrol, tetapi tidak dapat berfungsi sepenuhnya untuk mengontrol variabel-variabel luar yang mempengaruhi eksperimen. Desain penelitian yang digunakan adalah nonequivalent control group design. Sukmadinata (2006) mengatakan bahwa desain ini membandingkan kelas kontrol dan kelas eksperimen tetapi pengambilan tidak dilakukan secara acak penuh.

Teknik pengumpulan data yang digunakan adalah observasi berupa pengamatan aktivitas guru dan siswa selama proses pembelajaran dengan cara mengisi lembar observasi guru dan lembar observasi siswa, dokumentasi dan tes berbentuk uraian dengan jumlah enam butir soal untuk mengukur kemampuan komunikasi matematika siswa pada kelas eksperimen dan kelas kontrol sebelum dan sesudah diberi perlakuan. Data siswa diperoleh dari skor pretes dan skor postes. Sebelum itu, perlu dilaksanakan uji coba soal tes untuk mengetahui validitas, reliabilitas, daya pembeda dan tingkat kesukaran soal.

Instrumen yang digunakan dalam penelitian ini adalah Rencana Pelaksanaan Pembelajaran atau RPP, Lembar Aktivitas Siswa atau LAS, Lembar Aktivitas Kelompok atau LAK dan soal tes untuk mengukur kemampuan komunikasi matematika siswa.Prosedur dilaksanakan dengan tahapan-tahapan sebagai berikut: pemberian pretes (tes awal), pemberian perlakuan dengan model Missouri Mathematics Project dan pemberian postes (tes akhir).

Analisis data awal menggunakan uji normalitas menggunakan Chi Kuadrat, uji homogenitas menggunakan ujiF dan uji hipotesis setelah diberi perlakuan menggunakan uji t. Sedangkan data akhir menggunakan uji normalitas menggunakanChi Kuadrat, uji homogenitas menggunakan uji $\mathrm{F}$ dan uji hipotesis setelah diberi perlakuan menggunakan uji t. 


\section{HASIL PENELITIAN DAN PEMBAHASAN}

Hasil analisis data diperoleh skor mean kelas eksperimen dan skormean kelas kontrol. Skor mean kelas eksperimen yang menggunakan model Missouri Mathematics Project adalah 16,64; sedangkan skor mean kelas kontrol yang menggunakan pembelajaran konvensional adalah 13,68. Hal ini menunjukkan bahwa skor mean kelas eksperimen lebih tinggi dari pada skor mean kelas kontrol.

Dari hasil uji hipotesis dengan menggunakan Uji t dilakukan pada taraf signifikansi $5 \%$ dengan $\mathrm{df}=42$, diperoleh nilai $\mathrm{t}_{\text {hitung }}=2,42$ dan $\mathrm{t}_{\text {tabel }}=2,02$. Berikut disajikan rekapitulasi hasil analisis data dengan menggunakan Uji $\mathrm{t}$ pada Tabel 1.

Tabel 1. Rekapitulasi Analisi Uji Hipotesis

\begin{tabular}{|c|c|c|c|c|c|c|}
\hline Kelas & $\mathbf{N}$ & $\mathbf{D f}$ & $\boldsymbol{x}$ & $\mathbf{S}$ & $\begin{array}{c}\mathbf{t}_{\text {hitun }} \\
\mathbf{g}\end{array}$ & $\mathbf{t}_{\text {tabel }}$ \\
\hline Eksperimen & 22 & \multirow{2}{*}{42} & 16,64 & 3,30 & \multirow{2}{*}{2,42} & \multirow{2}{*}{2,02} \\
\cline { 1 - 4 } \cline { 4 - 5 } Kontrol & 22 & & 13,68 & 4,53 & & \\
\hline
\end{tabular}

Tabel 1 di atasmenunjukkan $t_{\text {hitung }}=2,42$ dan $t_{\text {tabel }}=2,02 . t_{\text {hitung }}>$

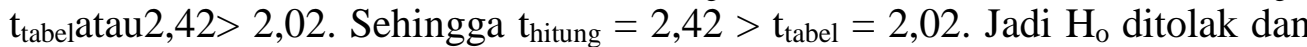
$\mathrm{H}_{\mathrm{a}}$ diterima. Artinya bahwa terdapat perbedaan antara kemampuan komunikasi matematika siswa yang belajar menggunakan model Missouri Mathematics Project dengan siswa yang belajar menggunakan pembelajaran konvensional pada materi persamaan lingkaran. Adanya perbedaan ini membuktikan, penerapan model Missouri Mathematics Project berpengaruh positif terhadap kemampuan komunikasi matematika siswa. Menurut Sugiyono (2010) bahwa jika kelompok treatment lebih baik dari pada kelompok kontrol, maka perlakuan yang diberikan pada kelompok treatmentberpengaruh positif.Dengan demikian dapat diketahui bahwa model Missouri Mathematics Project merupakan model pembelajaran yang dapat meningkatkan kemampuan komunikasi matematika siswa.

Pengambilan data analisis lembar observasi dilaksanakan di kelas XI TKJ SMK Dwi Sejahtera Pekanbaru selama empat pertemuan. Lembar observasi terdiri atas lembar observasi aktivitas guru dan lembar observasi aktivitas siswa. rata-rata aktivitas guru di kelas adalah $81,25 \%$, terlihat juga pada total skor dari pertemuan awal sampai pertemuan terakhir mengalami peningkatan. Rata-rata aktivitas siswa di kelas adalah $75 \%$, terlihat juga pada total skor dari pertemuan awal sampai pertemuan terakhir mengalami peningkatan. Hal ini menunjukkan peningkatan aktivitas siswadan guru dalam pembelajaran menggunakan model Missouri Mathematics Project. 


\section{PENUTUP \\ Kesimpulan}

Berdasarkan hasil penelitian, dapat dikemukakan bahwa ada perbedaan antara kemampuan komunikasi matematika siswa SMK Dwi Sejahtera Pekanbaru antara siswa yang diterapkan model Missouri Mathematics Project dan siswa yang diterapkan pembelajaran konvensional. Perbedaan tersebut dapat dilihat dari nilai $t_{\text {hitung }}=2,42$ dan $t_{\text {tabel }}=2,02$. Berdasarkan kaidah keputusan pengujian hipotesis pada taraf kepercayaan 5\% diketahui bahwa nilai $t_{\text {hitung }}>t_{\text {tabelatau }} 2,42>2,02$, berarti $\mathrm{H}_{\mathrm{a}}$ diterima dan $\mathrm{H}_{\mathrm{o}}$ ditolak.Dari hasil tes diperoleh skor mean kelas eksperimen yang menggunakan model Missouri Mathematics Project adalah 16,64, sedangkan skor mean kelas kontrol yang menggunakan pembelajaran konvensional adalah 13,69. Hal ini menunjukkan bahwa skor mean kelas eksperimen lebih tinggi dari pada skor mean kelas kontrol. Hal ini berarti penerapan model Missouri Mathematics Project dalam pembelajaran matematika lebih baik dari pembelajaran konvensional.

Dari penjelasan tersebut, adanya perbedaan ini membuktikan bahwa penerapan model Missouri Mathematics Project berpengaruh positif terhadap kemampuan komunikasi matematika siswa SMK Dwi Sejahtera Pekanbaru kelas XI semester ganjil tahun ajaran 2014/2015.Dengan demikian dapat diketahui bahwa model Missouri Mathematics Project merupakan model pembelajaran yang dapat meningkatkan kemampuan komunikasi matematika siswa.

\section{Saran}

Berdasarkan hasil penelitian ini, peneliti memberikan saran yang berhubungan dengan penerapan model Missouri Mathematics Project dalam pembelajaran matematika sebagai berikut:

a. Petunjuk pengerjaan yang ada pada LKS atau tugas proyek hendaknya disusun dengan jelas dan soal yang diberikan harus lebih kontekstual.

b. Penelitian ini hanya diterapkan pada materi persamaan lingkaran, penulis menyarankan supaya diterapkan pada materi matematika yang lain.

c. Dalam menerapkan model Missouri Mathematics Project ini, masih ada beberapa siswa yang kurang aktif dalam melaksanakan diskusi. Diharapkan guru agar bisa mengontrol siswa secara maksimal dalam kegiatan diskusi.Jadi disarankan kepada guru agar lebih optimal dalam mengkoordinir siswa dan memperhatikan penggunaan waktu dalam proses pembelajaran. 
d. Sebaiknya siswa yang mempresentasikan hasil kelompok adalah seluruh anggotanya dengan tujuan agar semua anggota kelompok dapat merasakan pengalaman menjelaskan materi di depan kelas.

e. Pada saat melakukan penelitian, penulis mengalami kesulitan mencari ataupun membuat soal yang cocok untuk mengukur kemampuan komunikasi matematika siswa. Oleh karena ini hendaknya guru lebih selektif lagi dalam mencari atau membuat soal yang dapat mengukur kemampuan komunikasi matematika siswa.

f. Penelitian ini hanya memfokuskan pada kemampuan komunikasi matematika siswa, peneliti menyarankan untuk peneliti lain agar dapat meneliti kemampuan siswa yang lain, misalnya kemampuan pemecahan masalah, pemahaman konsep, kemampuan berpikir kritis, kemampuan berpikir kreatif, penalaran dan koneksi matematika.

\section{DAFTAR PUSTAKA}

Jannah, M, Triyanto dan Henny, E. (2013).Jurnal Pendidikan Matematika Solusi, Vol 1. No 1. Penerapan Model Pembelajaran Missouri Mathematics Project untuk Meningkatkan Pemahaman dan Sikap Positif Siswa.

Krismanto, Al dan Widyaiswara. (2003). Beberapa Teknik, Model dan

Strategi dalam Pembelajaran Matematika. Yogyakarta: Departemen Pendidikan Nasional.

Rosani.Dunia Matematika; Model Missouri Mathematics Project. [Online]. Tersedia : http://math4usq.wordpress.com/category/uncategorized/. [ 2 Juni 2014 ].

Sugiyono. (2012). Metode Penelitian Pendidikan Pendekatan Kuantitatif, Kualitatif, dan $R \& D$. Jakarta : Alfabeta.

Sukmadinata, N S. (2006). Metode Penelitian Pendidikan. Bandung: PT Remaja Rosda karya.

Umar, W. (2012). Jurnal Infinity Vol 1, No. 2. Membangun Kemampuan Matematis dalam Pembelajaran Matematika. Siliwangi : STKIP Siliwangi. 